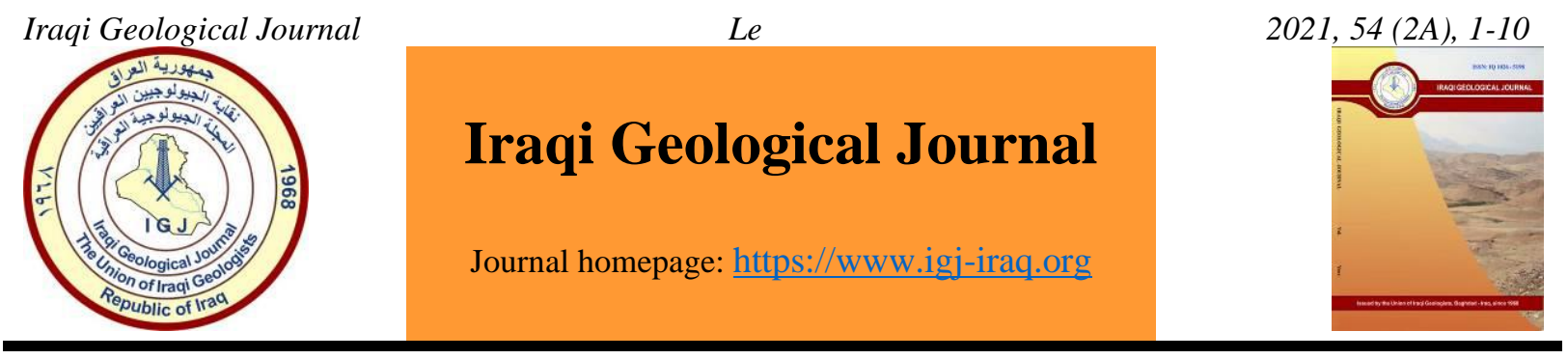

\title{
Seismic Characteristics of Mud Diapir in Song Hong Basin, Offshore Vietnam
}

\author{
Anh Ngoc Le ${ }^{1, *}$ \\ ${ }^{1}$ Hanoi University of Mining and Geology, Vietnam \\ *Correspondence: lengocanh@humg.edu.vn \\ Received: 23 March 2021; Accepted: 28 April 2021; Published: 30 July 2021
}

\begin{abstract}
Seismic characteristics of mud diapir have been investigated over an area of $3900 \mathrm{~km}^{2}$, located in the centre of the Song Hong basin, using four 2D seismic lines. There are six mud diapirs and three mud pipes that have been documented. The core of the diapir is characterized by a zone of chaotic, disrupted seismic reflection, with the amplitude reflection ranging from low the high. High amplitude reflections are distributed at the top of some diapir, which is possibly related to gas accumulation. They are in different sizes, shapes, and the relationship with surrounding rock. They are characterized as deep sourced, high energy rooting from Oligocene-/early Miocene shale layers. These organic-rich shale rocks are in the oil and gas windows, thus their hydrocarbon generation combining with the tectonic inversion during Miocene make the overpressured shale and therefore rising the diapirs. The area has experienced several phases of eruption in the Middle Miocene, Late Miocene, Late Pliocene, and Present day. The discovery and identification of the occurrence of mud diapirs implied a great potential for the prediction of structural traps in the central part of the Red River Basin.
\end{abstract}

Keywords : Mud diapir; Song Hong Basin; Hydrocarbon potential

\section{Introduction}

Diapirs are domes created by deformations of mobile sediments; they may deform or disrupt overlying rocks. During the diapir evolution, if it reaches to the surface, it will be termed a mud volcano. Mud volcanoes can be observed on the crest of the diapirs (Dimitrov, 2002). Diapir evolution is proposed to have four evolutionary phases, including reactive, active, passive, and diapir collapse. Each phase is resulted by several control factors i.e., regional tectonics, the differences in density between the mobile sediments and its overburden rock, sedimentation rate, even though these phases originally use for salt diapir evolution, even though, it still can be applied for the mud diapir as they have similar mechanisms. (Morley and Guerin, 1996; Van Rensbergen et al., 1999). Mud diapirs have been linked to both extensional and compressional stress regimes. Rapid sedimentation and hydrocarbon generation will cause overpressure in sediment layers, triggering the diapir evolution (Dimitrov, 2002; Milkov, 2000; Talukder et al., 2003); Tectonic processes are considered to be the main driving forces for the development of mud diapirism (Milkov, 2000; Talukder et al., 2007).

The Song Hong Basin is one of the largest Tertiary sedimentary basins situated in the continental margin of the East Sea. Its formation is often considered to be linked with the timing and motion of the

DOI: $\underline{10.46717 / \text { igj.54.2A.1Ms-2021-07-22 }}$ 
Ailao Shan-Red River Strike-slip Fault Zone and transtensional break-up of the pre-Cenozoic basement along the East Sea during the Cenozoic (Fyhn et al., 2018). Previous studies are based on 2D and 3D multichannel seismic data have documented the occurrence of mud diapirs, focused fluid flow, and gas seeps within the Song Hong Basin (Zhenfeng and Baojia, 2008; Nguyen-Hiep, 2019; Wan et al., 2019). Although these mud diapirs are of importance for the formation of structural traps, their characteristics, formation timing, and mechanism are still poorly documented in this area. This paper focuses on the characterization of mud diapir structures by detail seismic facies analysis of 2D seismic lines cutting across the central Song Hong Basin (Fig. 1). We will further investigate the controls on mud diapir generation and evolution in the area and also the hydrocarbon potential of the basin.

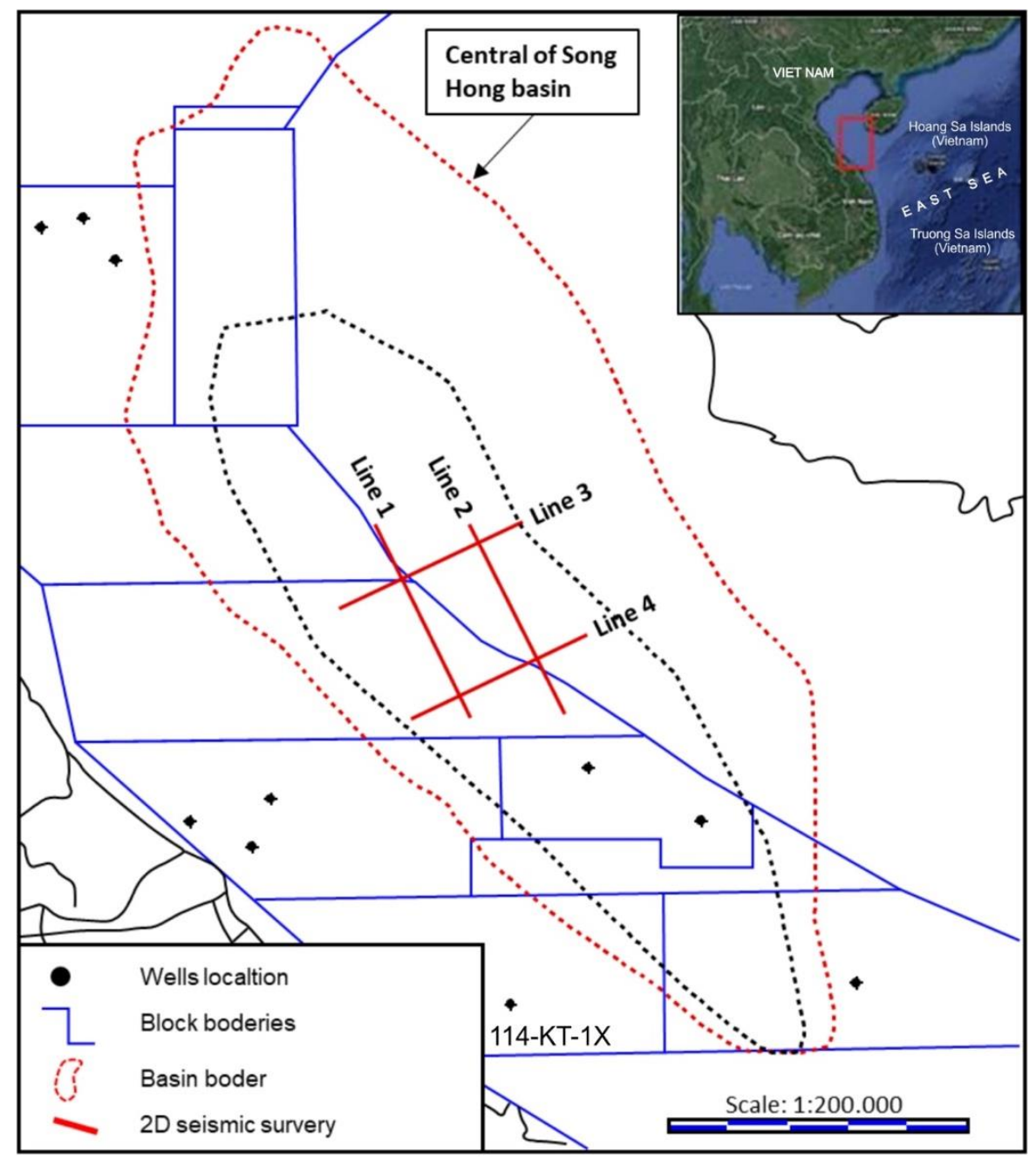

Fig. 1. The study area is located in the central of Song Hong basin, covering an area of $3900 \mathrm{~km}^{2}$ with the locations of four seismic lines used in this study (adapted from Nguyen-Hiep, 2019).

\section{Geological Setting}

Song Hong Basin is a passive continental margin of the northern East Sea, commencing in Mesozoic time. It has northwest-trending transform extension (Fyhn et al., 2018). The basin is documented as the largest Tertiary basin on the continental shelf of Vietnam and classified as a pull-apart basin. The total thickness of the basin is up to $15 \mathrm{~km}$. During Late Eocene, the collision of the Indian sub-continent plate with the Asia plate is to the onset of the basin's formation. The basin experienced two main phases, syn-rift and post-rift. Syn-rift deposition in Eocene-Oligocene was filled 
by lacustrine sediment with a rapid sedimentation rate. The basin was fully marine environment since Early-Middle Miocene (Fig. 2).

The central basin was documented high geothermal gradients, from 42 to $45.1{ }^{\circ} \mathrm{C} / \mathrm{km}$, overpressure in Oligocene organic-rich shale which is the main control on the development of mud diapirs in the area (Nguyen-Hiep, 2009). The diapiric structures are different in size and shape, occurring in dissimilar stratigraphic horizons. Several gas fields have been discovered above the diapir structure, above the overpressure system (Zhenfeng and Baojia, 2008).

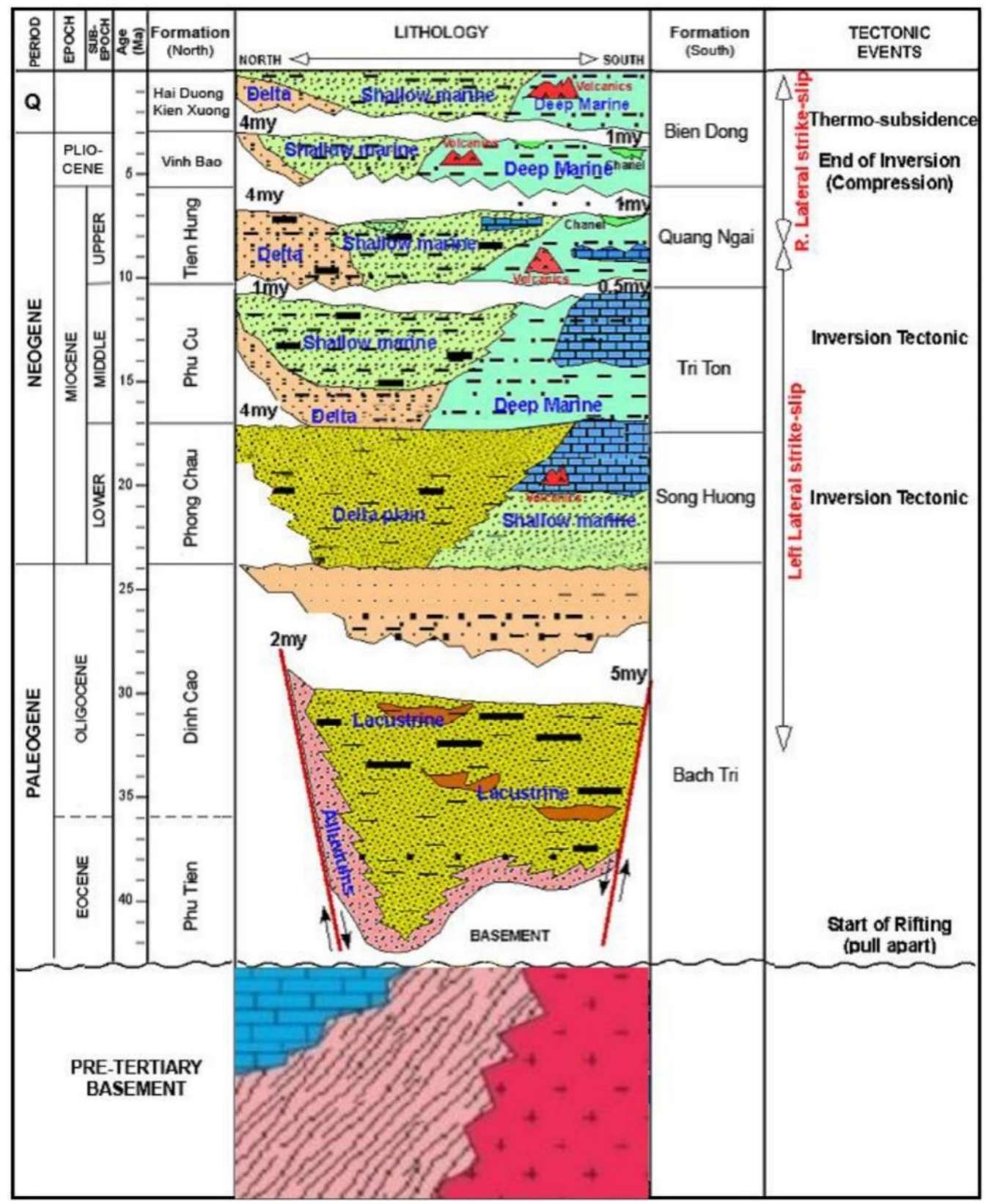

Fig. 2. Stratigraphic chart of the central Song Hong basin (Nguyen-Hiep, 2019)

\section{Dataset and Methodology}

This study using high quality 2D seismic data in the centre of the Song Hong basin. The data includes 4 seismic lines, line 1, 2, 3, and 4, seismic line is about $60 \mathrm{~km}$ long and apart from each other 28 $\mathrm{km}$ and $45 \mathrm{~km}$ (Fig. 1). The dataset is c. 130km offshore, located in block 111 of the central Song Hong basin. 
Seismic interpretation of the mud diapirs was proceeded on the workstation, using Petrel software version 2013. Seismic facies and seismic attributes analysis have been applied to construct the outline of the diapirs i.e., chaos, RMS. Approximate ages of interpreted horizons-based correlation to well data in the nearby area were given along with the seismic sections.

\section{Results}

The mud diapirs are observed on every seismic profile (Fig. 3 and Table 2), characterized as a relatively vertical zone of chaotic, low to high amplitude reflections, up to $5500 \mathrm{~ms}$ TWT length and diameter of about $2-25 \mathrm{~km}$. The diapir normally has a larger diameter at depth and narrower upward. The core of the diapir is a zone of chaotically disrupted seismic reflections ranging from high to low amplitude reflection. High amplitude, chaotic seismic facies are mainly on the top of the diapirs (Figs. 4, 5 and 6).

Mud diapirs have different sizes, shape, and the relationship with surrounding rock (Table 1). They are characterized as deep sourced, high energy and appear in a great variety forms as a cone shape, pipe shape, and funnel shape (Fig. 3). Their top is either flat, or bulb, or plateau. Among those, a large-scale funnel shape diapir (diapir 3) has a depression top which can be mapped quite clearly as it is located in the crossover position of lines 2 and 3 (Fig. 3). There are four levels of the diapir terminations, below KS-1, KS-2, KS-3, and the seafloor. Key surfaces KS-1, KS-2, KS-3 are corresponding to the top middle Miocene, top upper Miocene, top Pliocene, respectively (Fig. 4). The diapirs appear to have a deep source, however, the mud source layer of the diapirs is not seen on the four seismic lines, which is possibly beyond the lower limit of the data. Mud diapir structure terminated at different stratigraphic levels making sediment layers on both sides of the diapirs gently uplifted (Figs. 5 and 6). Most diapirs became inactive below the KS-2 reflection, others pierced the upper sequences and continued their upward migration vertically up to the seafloor (diapir 4 and 6). These active diapirs dominated in the southeast area.

Table 1. Mud diapir types in the central of Song Hong basin. Three types of diapir are defined in the study area based on the difference in size, shape, and eruption intensity.

\begin{tabular}{|c|c|c|}
\hline Diapir type & Development characteristics & Seismic facies \\
\hline $\begin{array}{l}\text { Deep source, high } \\
\text { energy, large scale } \\
\text { funnel diapir }\end{array}$ & $\begin{array}{l}\text { Up to } 25 \mathrm{~km} \text { wide, } 4.5 \mathrm{~s} \text { long, depression } \\
\text { top. Terminated under KS-1, diapir } 3\end{array}$ & $\begin{array}{l}\text { Low amplitude, chaos } \\
\text { reflections }\end{array}$ \\
\hline $\begin{array}{l}\text { Deep source, high } \\
\text { energy, cone shape } \\
\text { diapir }\end{array}$ & $\begin{array}{l}5 \text { - } 8 \mathrm{~km} \text { wide, up to } 5.5 \mathrm{~s} \text { long } \\
\text { - Terminated as flat/bulb top } \\
\text { Burial diapirs below KS-2 (diapir } 1,2,5) \\
\text { Active diapir on the seafloor (diapir } 4) \\
\text { Christmas-tree' structure preserved in } \\
\text { diapir } 4 \text { and } 5\end{array}$ & $\begin{array}{l}\text { Low to high amplitude, } \\
\text { chaotic reflection. High } \\
\text { amplitude reflections } \\
\text { mainly observed near the } \\
\text { top of the diapirs }\end{array}$ \\
\hline $\begin{array}{l}\text { Deep source, high } \\
\text { energy mud pipe/gas } \\
\text { chimney }\end{array}$ & $\begin{array}{c}\text { About } 2 \mathrm{~km} \text { wide column of mud pipe } \\
01 \text { active pipe on line } 3 \\
02 \text { burial pipes on line } 1 \& 4\end{array}$ & $\begin{array}{l}\text { High to low amplitude, } \\
\text { disturbed seismic } \\
\text { reflections }\end{array}$ \\
\hline
\end{tabular}

Mud diapir in the central of Song Hong basin developed in the Neogene-Quaternary marine sequences, mainly formed in the late Miocene. The diapir bodies have many forms of blurry or transparent reflections with high amplitude on the top or along the boundaries of the diapir. The occurrence of burial (Fig. 6a) and active mud pipes (Fig. 5) indicates strong fluid leakage. Mud pipe can 
be considered as a small diapir and have a columnar shape. The diapir 3 is the largest diapir with a funnel shape and a collapsed depression crater. This collapse structure has been mentioned by Istadi et al. (2012). According to these authors, once the volcano eruption is emitted, it gradually collapsed around the vertical feeder channel. In this case, the occurrence of many faults dipping toward the diapir and terminated in the KS-1 associated with high deformation of the country rocks around the diapir 3 in the upper Miocene and Pliocene sequence (Fig. 5) is caused by the intrusive structure resulting in faulting and gravitational slumps. The gradual collapse process resulted in the widening upward of the diapir.

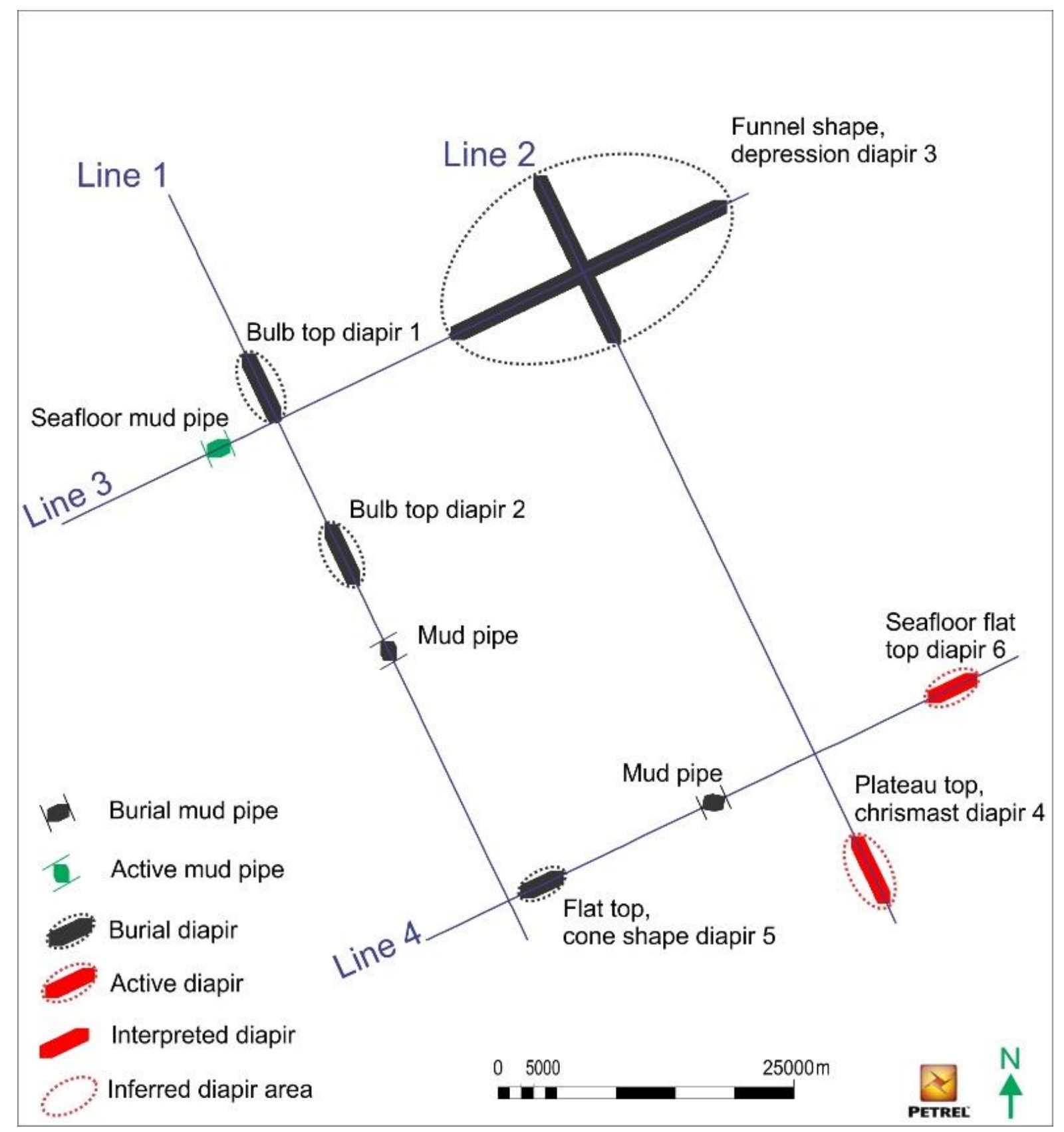

Fig. 3. The occurrence of mud diapirs and mud pipes in the study area. 

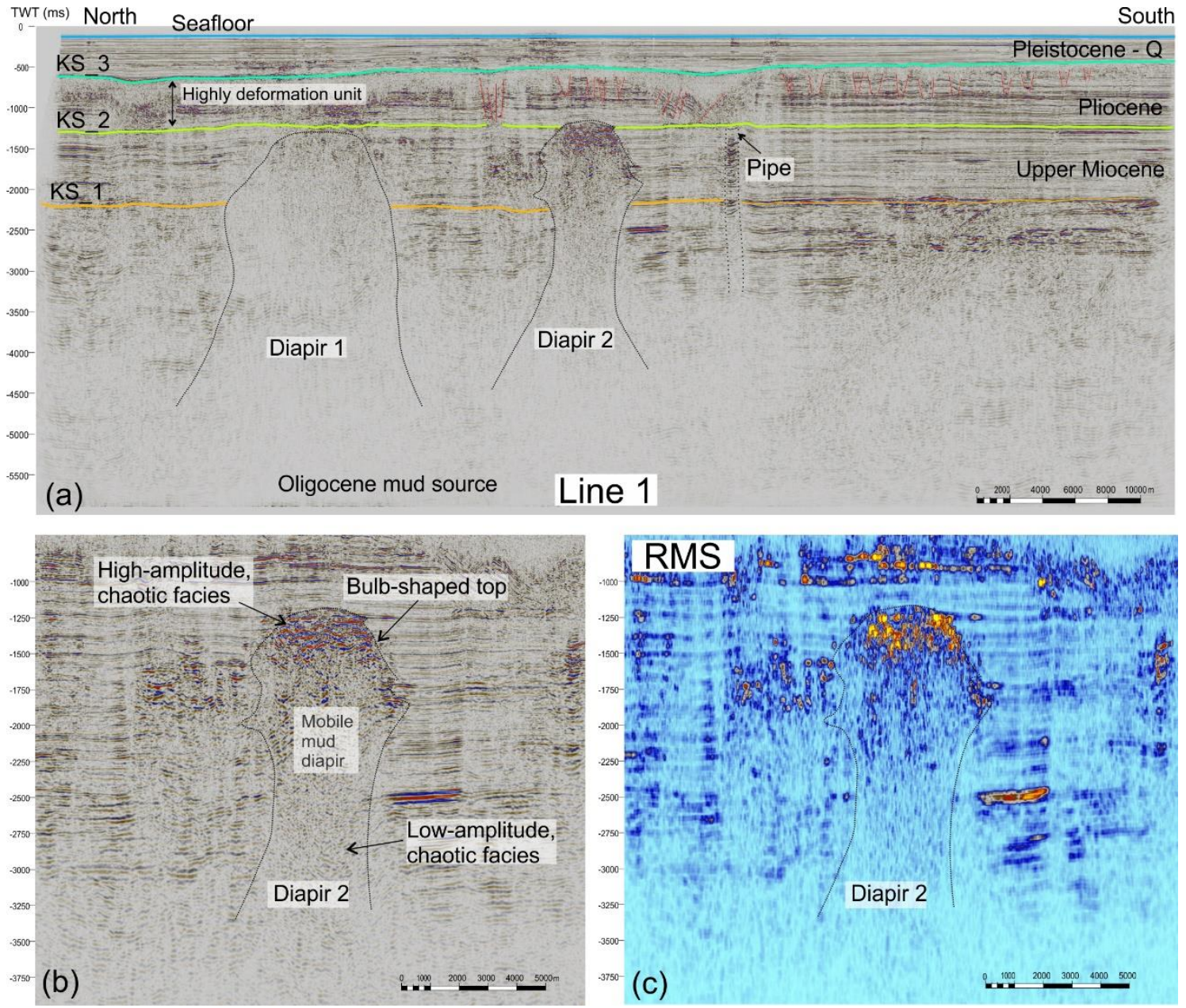

Fig. 4. (a) Seismic line 1 with the burial diapir 1, diapir 2, and a burial mud pipe. They all terminated under the KS-2 surface. The image of the diapir 2 is zoomed in to see the detailed characteristics of the diapir (b) combining with its RMS attribute shown in c

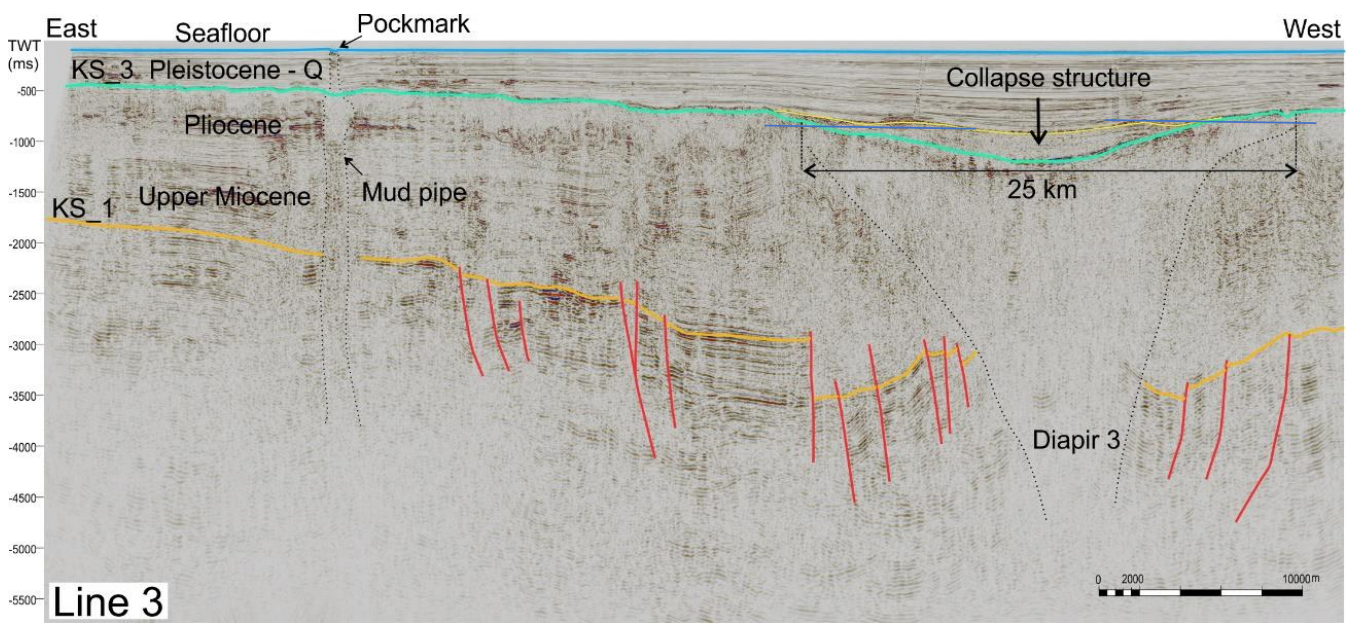

Fig. 5. A seismic line 3 showing the largest diapir (diapir 3) interpreted as a collapsed structure and an active mud pipe. The area around diapir 3 is highly faulted and deformed caused by the volcano eruption and subsidence 

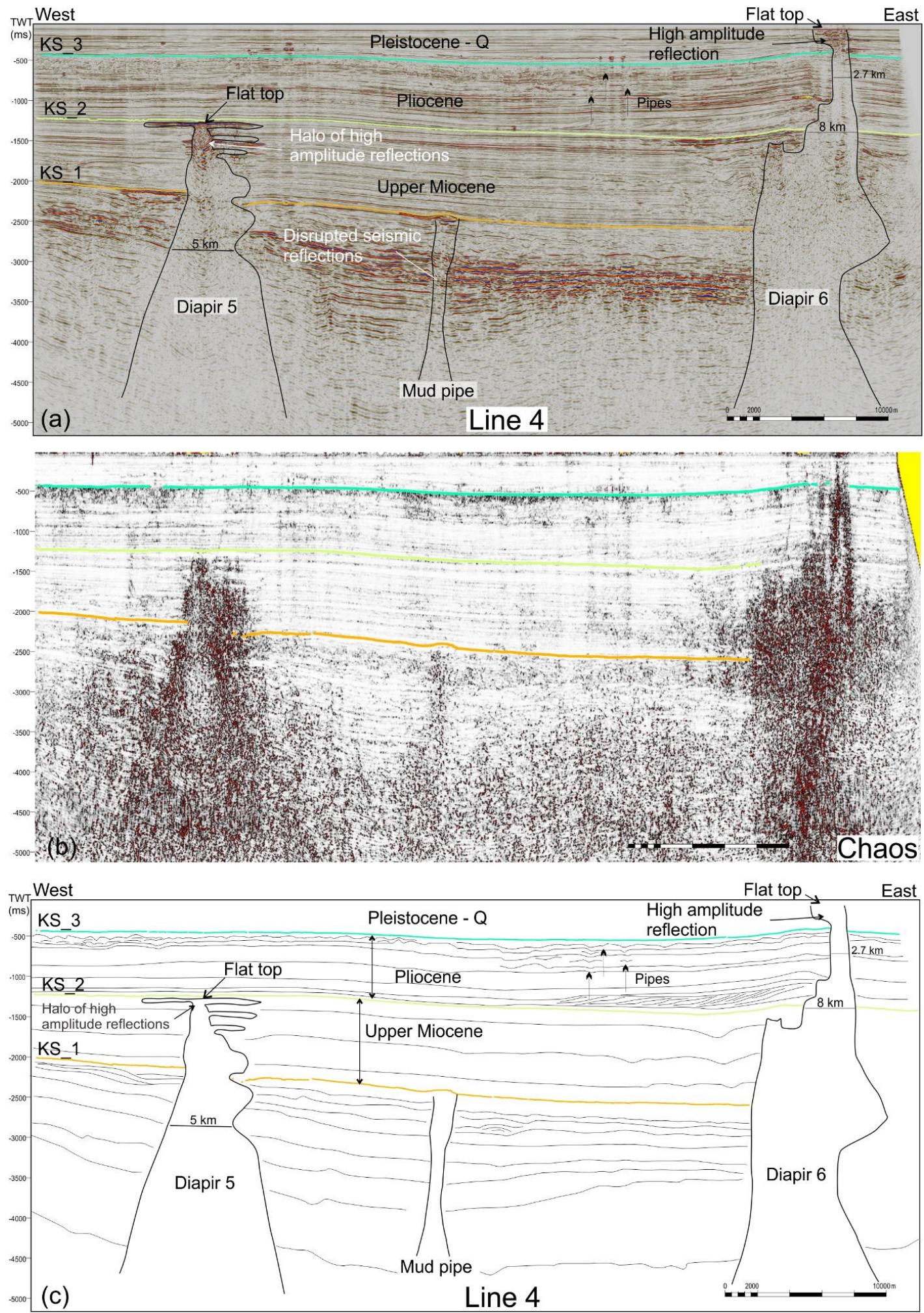

Fig. 6. (a) Seismic line 4 showing a burial diapir 5 and active diapir 6 . The mud pipe terminated under the KS-1 surface and the burial diapir 5 terminated under KS_2. The eruptions may be triggered by deep overpressure fluid of Oligocene-early Miocene shale. The area has experienced several phases of eruption in the Middle Miocene, Late Miocene, Late Pliocene, and Present day. (b) Chaos attribute of line 4 showing the chaos zones associated with the diapir structures. (c) A line drawing to capture the overall interpretation of the diapir and sequences of the seismic line 4 


\section{Discussion}

\subsection{Mud Diapir Development}

There are many diverse views on mud volcano eruptions. The eruptions are considered to be initiated by deep overpressure fluid, fault activity, earthquake, drilling, or other factors (Roberts et al., 2011; Sun et al., 2012; Wan et al., 2015). In the Song Hong basin, the occurrence of mud diapirs has been documented in the central part where the total thickness of the sedimentary basin is up to $10 \mathrm{~km}$. The triggering mechanism of mud volcano is supposed to be overpressured fluid caused by the hydrocarbon generation of the deep source layers. In the central Song Hong basin, two important source rocks are the Oligocene and Lower Miocene shales. Core analyses in well 114-KT-1X indicated that Lower Miocene source rocks are of excellent quality and in matured. Meanwhile, the thick Oligocene source rock have already in the dry gas generation window (Nguyen-Hiep, 2019). The gas generation window is estimated to present at depth $3800 \mathrm{~m}-5300 \mathrm{~m}$ (Zhenfeng and Baojia, 2008). This depth is responsible for the lower section and beyond the study interval. The halo high - amplitude reflections in the top of the diapir and above it (Figs. 4 and 5) are supposed to represent the occurrence of hydrocarbon accumulations in the sediment. This kind of hydrocarbon accumulation has been documented in many different settings (Hovland, 1990; Van Rensbergen et al., 1999).

Mud volcano is rooted in the Oligocene-Early Miocene sequences and experienced many active phases from the middle Miocene onwards. According to (Hovland, 1990; Van Rensbergen et al., 1999), diapir evolution includes four phases: reactive, active, passive, and diapir collapse. In this case study, Reactive diapirism is possibly responded to different loading of mobile shale layers, occurring in the early stage of diapir evolution in which tectonic inversion causes the different load on the Oligocene/Mid Miocene mobile shale. Besides, hydrocarbon generation will cause overpressed in the mobile shale leading to the reactivation of the diapir more rapidly. In the stage of active diapirism, hydraulic fracturing, differential loading, and buoyancy are the factors controlling the shale rise (Van Rensbergen et al., 1999). Once the diapir reaches the shallow subsurface, it passes into the passive diapirism with the downbuilding of the flanks (Worrall and Snelson, 1989). Diapir will fall into the collapse stage due to the volume loss caused by venting of overpressured fluids (Van Rensbergen et al., 1999). This collapse stage is observed clearly in diapir 3. In this diapir, apart from the volume loss, the widespread lateral extension of the diapir itself up to $25 \mathrm{~km}$ is also an important factor causing the collapse of the diapir.

\subsection{Hydrocarbon Potential in Song Hong Basin}

The diapir structure in the Song Hong basin also developed in the China part; the drilling results proved that the mud diapir is related to the accumulation of natural gas, such as the Dongfang 1-1 (DF1-1). This mud diapir gas field was discovered in 1992 with a proven gas reserve of $99.68 \times 109 \mathrm{~m}^{3}$ (Zhenfeng and Baojia, 2008). This gas field is a type of anticline structure, formed above the mud diapir. Anticline structural trap plays an important role to trap hydrocarbon (Alhadithi and Al-Hadithy, 2020). In the part of Vietnam, the exploration has been focused on the anticline and stratigraphic traps related to diapirs, the drilling of the Bao Vang (BV-1X) was proved for the gas potential with the relatively equivalent volume of Dongfang field, $107.3 \times 109 \mathrm{~m} 3$. The occurrence of the diapirs and the proved gas field indicated the role of diapir to form the traps and the migration pathways for the hydrocarbon to migrate from the source to accumulate in the shallower. In this case study, the halo high amplitude reflections observed on the top of some diapirs are possibly caused by gas accumulation which needs to be investigated for the hydrocarbon potential in the area. 


\section{Conclusions}

Mud diapirs in the central of Song Hong basin developed in the Neogene-Quartary marine successions, with several active phases in Middle Miocene, Late Miocene, Late Pliocene, and Present day. The diapirs are characterized as a relatively vertical zone of chaos or transparent reflections, and high amplitude reflection especially on the top of the diapir. There are 6 diapirs and 3 mud pipes that have been documented. Diapir and pipe occur in both active and passive forms. Active diapirs concentrated in the southeast of the study area. They are deep source, high energy diapirs, rooting from Oligocene-early Miocene shale layer. The halo high amplitude reflections dominated in the top of the diapirs suggest for the hydrocarbon accumulation, mainly gas, which need to be investigated for future hydrocarbon exploration in this study area.

\section{Acknowledgements}

I would like to thank Schlumberger for Petrel software support. I also would like to thank my colleges for valuable discussions during the interpretation work of this paper. I also gratefully thank the reviewers for the time and care they have taken in reading and reviewing this paper. The authors are very grateful to the Editor in Chief Prof. Dr. Salih M. Awadh, the Secretary of Journal Mr. Samir R. Hijab. and the Technical Editors for their great efforts and valuable comments.

\section{References}

Alhadithi, N. H., Al-Hadithy, A. A. 2020. Differential entrapment of charged hydrocarbon in Alan field, northern Iraq. The Iraqi Geological Journal, 53 (2A), 68-76.

Dimitrov, L. I. 2002. Mud volcanoes-the most important pathway for degassing deeply buried sediments. Earth-Science Reviews, 59, 49-76.

Fyhn, M. B., Cuong, T. D., Hoang, B. H., Hovikoski, J., Olivarius, M., Tuan, N. Q., Tung, N. T., Huyen, N. T., Cuong, T. X. \& Nytoft, H. P. 2018. Linking Paleogene rifting and inversion in the Northern Song Hong and Beibuwan Basins, Vietnam, With left-lateral motion on the Ailao Shan-Red River Shear Zone. Tectonics, 37, 2559-2585.

Hovland, M. 1990. Suspected gas-associated clay diapirism on the seabed off Mid Norway. Marine and Petroleum Geology, 7, 267-276.

Istadi, B. P., Wibowo, H. T., Sunardi, E., Hadi, S., Sawolo, N. \& Dar, I. 2012. Mud volcano and its evolution. Earth sciences: In Tech, 375-434.

Milkov, A. 2000. Worldwide distribution of submarine mud volcanoes and associated gas hydrates. Marine Geology, 167, 29-42.

Morley, C. K., Guerin, G., 1996. Comparison of gravity-driven deformation styles and behavior associated with mobile shales and salt. Tectonics, 15, 1154-1170.

Nguyen-Hiep, 2019. The Petroleum Geology and Resources of Vietnam, 2nd edition. Science and Technics Publishing House.

Roberts, K. S., Davies, R. J., Stewart, S. A., Tingay, M. 2011. Structural controls on mud volcano vent distributions: examples from Azerbaijan and Lusi, east Java. Journal of the Geological Society, 168, 1013-1030.

Sun, Q., Wu, S., Cartwright, J., Dong, D. 2012. Shallow gas and focused fluid flow systems in the Pearl River Mouth Basin, northern South China Sea. Marine Geology, 315, 1-14.

Talukder, A., Comas, M., Soto, J. 2003. Pliocene to Recent mud diapirism and related mud volcanoes in the Alboran Sea (Western Mediterranean). Geological Society, London, Special Publications, 216, 443-459.

Talukder, A. R., Bialas, J., Klaeschen, D., Bürk, D., Brückmann, W., Reston, T., Breitzke, M. 2007. High-resolution, deep tow, multichannel seismic and sidescan sonar survey of the submarine mounds and associated BSR off Nicaragua pacific margin. Marine Geology, 241, 33-43. 
Van Rensbergen, P., Morley, C., Ang, D., Hoan, T., Lam, N. 1999. Structural evolution of shale diapirs from reactive rise to mud volcanism: 3D seismic data from the Baram delta, offshore Brunei Darussalam. Journal of the Geological Society, 156, 633-650.

Wan, Z., Shi, Q., Zhang, Q., Cai, S., Xia, B. 2015. Characteristics and developmental mechanisms of mud volcanoes on the southern margin of the Junggar Basin, NW China. Geological Journal, 50, 434-445.

Wan, Z., Yao, Y., Chen, K., Zhong, S., Xia, B., Sun, Y. 2019. Characterization of mud volcanoes in the northern Zhongjiannan Basin, western South China Sea. Geological Journal, 54, 177-189.

Worrall, D., Snelson, S. 1989. Evolution of the northern Gulf of Mexico. The geology of North America; an overview: Geological Society of America, A, 97-138.

Zhenfeng, W., Baojia, H., 2008. Dongfang 1-1 gas field in the mud diapir belt of the Yinggehai Basin, South China Sea. Marine and Petroleum Geology, 25, 445-455. 